\title{
Annual pattern of calanoid copepod abundance, prosome length and minor role in pelagic carbon flux in the Solent, UK
}

\author{
A. G. Hirst*, M. Sheader, J. A. Williams \\ School of Ocean and Earth Science, University of Southampton, Southampton Oceanography Centre, Empress Dock, \\ Southampton SO14 3ZH, United Kingdom
}

\begin{abstract}
Investigation of the calanoid copepods at a coastal station in the Solent, UK, over a 14 mo period revealed a numerical dominance by species of the genus Acartia (comprising $A$. bifilosa, $A$. clausi, A. discaudata and A. margalefi), and the species Temora longicornis and Centropages hamatus, with sporadic appearances of Paracalanus parvus and Pseudocalanus elongatus. There was clear seasonality in the abundance of calanoids, with total numbers being highest from May onwards, and low after October Stage-specific prosome lengths varied with season, and in most cases were negatively correlated with temperature. Individual weights and abundance of the copepods, together with measures of temperature, were used to predict weight-specific growth and production rates using a published empirical relationship. Comparisons of annual copepod production with previous measures of annual primary production and production of bacteria and ciliates at this same site were made, and a carbon flow diagram was constructed. Calanoid copepod annual production was $32.2 \mathrm{mgC} \mathrm{m}^{-3} \mathrm{yr}^{-1}$ This represents only $0.5 \%$ of the total annual primary production, and $0.6 \%$ of the annual primary production of algae $>3 \mu \mathrm{m}$. Ciliate annual production was almost 2 orders of magnitude higher, and constituted $33 \%$ of the total annual primary production. In other neritic studies (with water column depths $<200 \mathrm{~m}$ ) annual production by copepods has varied between 21 and $177 \%$ of annual ciliate production, whereas at this Solent site the value was only $1.5 \%$. It is suggested that the low biomass (and production) achieved by calanoid copepods was the consequence of population loss through high local flushing rates, unfavourable feeding conditions resulting from high suspended particulate matter, and high levels of hydrocarbon contaminants in the area
\end{abstract}

KEY WORDS: Calanoid $\cdot$ Copepodite stage Prosome length $\cdot$ Abundance $\cdot$ Production $\cdot$ Solent

\section{INTRODUCTION}

The Solent is a marine body of water situated at the opening of Southampton Water, on the south coast of the UK. The area is heavily industrialised, with major petroleum refinery installations on the west side of Southampton Water, and, to the north, the large city of Southampton. Although surveys of the mesozooplankton of Southampton Water have been undertaken by several workers over many

\footnotetext{
-Present address: Department of Biological Sciences, HeriotWatt University, Riccarton, Edinburgh EH14 4AS, Scotland, United Kingdom. E-mail: a.hirst@hw.ac.uk
}

years, comprehensive species-specific examinations of the zooplankton in this body of water have not been undertaken since those by Raymont \& Carrie (1964). The Solent is situated to the north of the Isle of Wight, and is linked to the English Channel on either side of this island. Tidal features of the Solent are complex and characterised by a long stand of high water consisting of a double high tide, during which there is little water movement over a period of 2 to $3 \mathrm{~h}$ (Webber 1980). The Solent and Southampton Water are eutrophic, and the water column is partially to well mixed (Sylaios \& Boxall 1998). The Calshot site investigated here is at the confluence of Southampton Water and the Solent (Fig. 1), and is 


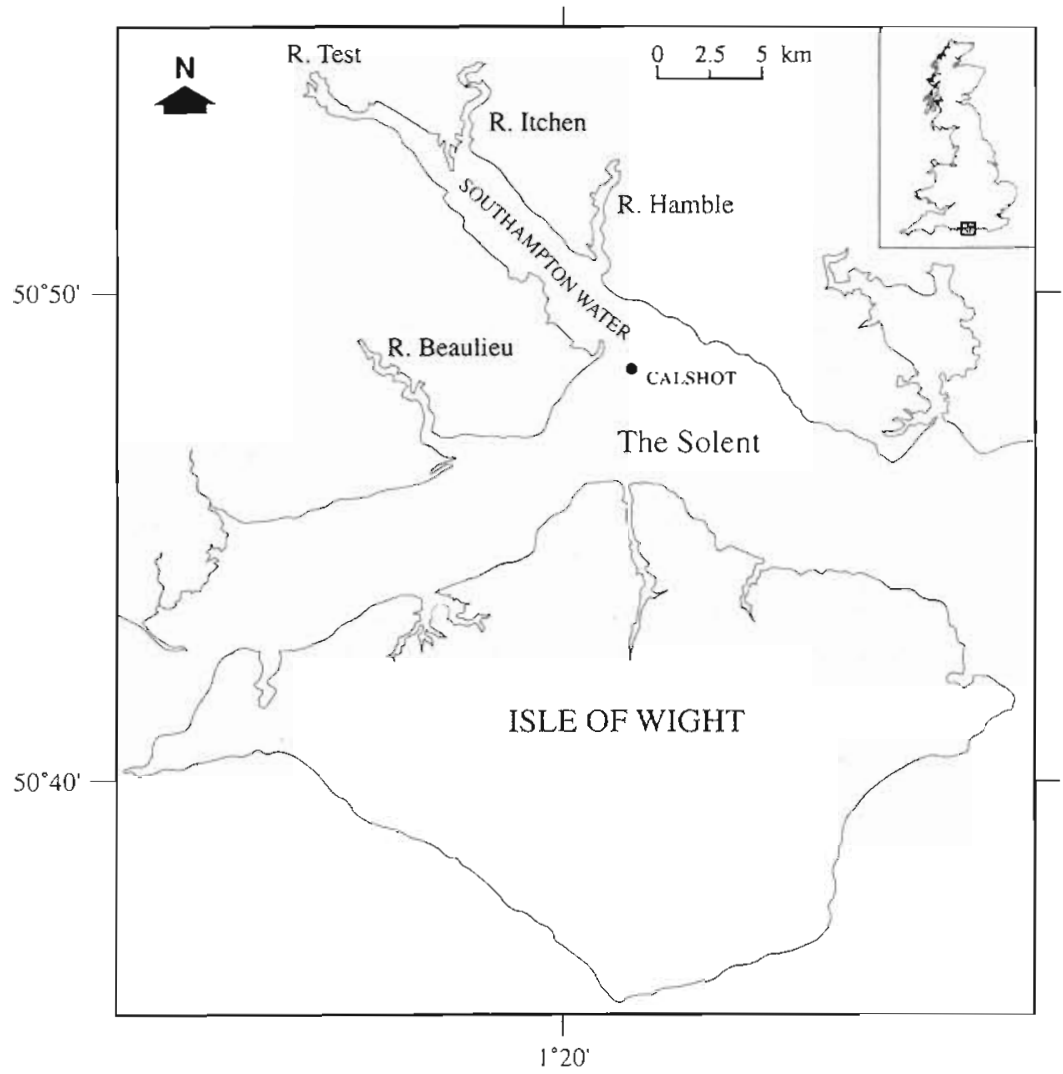

Fig. 1. Location of the Calshot site (the Solent, UK) investigated in the present study

located on the eastern limit of the dredged shipping channel.

This study forms part of an on-going investigation into the mesozooplankton of the area. The site has previously been used in examinations of the seasonal cycle, i.e. abundance, biomass and production rates of ciliates (Leakey et al. 1992), bacteria (Antai 1989) and size-fractionated primary production (Iriarte \& Purdie 1994). The present investigation was designed to add to the body of information on pelagic carbon flux at this particular site by measuring abundances of the calanoid copepods and by estimating their contribution to pelagic carbon fluxes.

\section{METHODS}

Zooplankton were collected at $5 \mathrm{~m}$ from a $15 \mathrm{~m}$ deep site in the Solent, marked by the Calshot fixed shipping buoy (Fig. 1), over a 14 mo period (December 1992 to January 1994). Samples were taken at the high tide 'stand' during daylight hours, as close to spring tide as boat facilities and weather would allow. Plankton samples were collected using a $118 \mu \mathrm{m}$ mesh non-filtering cod-end net (mouth opening diameter $50 \mathrm{~cm}$, net length $125 \mathrm{~cm}$ ). The mesh size chosen ensured coverage of most of the copepodite stages, whilst minimising the reduction in filtering efficiencies during the periodic phytoplankton blooms which occur here. The net was towed horizontally at a speed of 2 knots for less than 5 min. A calibrated T.S Flowmeter (Tsurumi-Seiki Co. Ltd) was fixed in the mouth of the net to determine the water volume filtered. After towing the net was washed thoroughly, and the catch preserved in $4 \%$ formaldehyde-sea water. On 2 occasions (12 March 93 and 26 March 93) the usual net could not be used and a $200 \mu \mathrm{m}$ mesh net was used as a replacement.

Temperature and salinity measurements were taken at 5 and $10 \mathrm{~m}$ depth, using a field T-S probe at each of the stations concurrently with the collection of zooplankton samples. Samples of water for pigment analysis were collected from 5 and $10 \mathrm{~m}$, using a $5 \mathrm{l}$ Niskin water bottle; samples were filtered through Whatman (GF/C) filters, and analysed fluorometrically for chlorophyll $a$ and phaeo-pigments after $90 \%$ acetone extraction (protocol described in Kifle 1992).

After storage of the zooplankton material in excess of 6 mo, samples were concentrated to a fixed volume, and $2 \%$ sub-samples taken using a Stempel pipette. The sub-samples contained very large amounts of sediment, detritus and phytoplankton material, and zooplankton was therefore carefully separated out with the aid of a S-shaped Bogorov tray and binocular microscope. All zooplankton were enumerated and identified, although this study presents detailed results for only the dominant calanoid copepod component (other components described in Hirst 1996). Copepodites were identified to species level, although in the case of Acartia the non-adult copepodites were only classified to genus, and separated into the groups: C1. C2, C3, C4 (sexed when possible), C5 female and male, and 66 female and male. Naupliar stages were not identified to species level but were counted. Prosome lengths were measured for all individuals using a calibrated eye-piece graticule (where 1 division equalled $8.91 \mu \mathrm{m}$ ), at a standard magnification of $100 \times$. No correction was made to these measurements as shrinkage due to preservation is minimal (Durbin \& Durbin 1978). Prosome length measurements were made on a total of 3966 individuals, and although 
a standard number were not measured for each copepodite stage, means often represent $>20$ individuals.

Individual carbon weights were estimated from prosome lengths using the regressions of Klein Breteler et al. (1982) for southern North Sea Acartia clausi, Centropages hamatus and Temora longicornis, while their equation for Pseudocalanus sp. was used to estimate weights of Paracalanus parvus and Pseudocalanus elongatus. Ash-free dry weight was converted to dry weight by assuming that ash represented $10.4 \%$ of the dry weight in $T$. longicornis, $8.9 \%$ in Acartia spp., $8.5 \%$ in Pseudo/Paracalanus and $4.1 \%$ in C. hamatus (Laurence 1976). Carbon weights were calculated assuming these to be $40 \%$ of dry weight (Omori \& Ikeda 1984, Båmstedt 1986). Adult Acartia weights were determined using the appropriate speciesspecific equation, whilst for non-adult copepodites the length-weight equation for whichever Acartia species was numerically dominant in the adult stage was applied. As there was no equation available for $A$. discaudata and $A$. margalefi, the equations for $A$. bifilosa and $A$. clausi respectively were applied (as body form is similar between these species). A bifilosa weights were determined using the equation describing carbon weight (C, $\mu \mathrm{gC}$ ) as a function of prosome length (PL, $\mu \mathrm{m}$ ), where $\log _{e} \mathrm{C}=-2.285+0.003793$ PL (M. Koski pers. comm.). Unfortunately, given the variation in stage abundances resulting from the mixing in the area, and the resolution of sampling, we made no attempt to describe growth using cohort methods. As an alternative, growth of copepods was estimated using the globally predictive equation of Hirst \& Lampitt (1998):

$$
\log _{10} g=0.0208(T)-0.3221\left(\log _{10} B W\right)-1.1408
$$

where $g\left(\mathrm{~d}^{-1}\right)$ is weight-specific growth, $\mathrm{T}\left({ }^{\circ} \mathrm{C}\right)$ is temperature, and $\mathrm{BW}\left(\mu \mathrm{gC}\right.$ ind ${ }^{-1}$ ) is individual body weight, adult males were assumed not to grow. Individual weights rather than mean values, and the temperature at the time of sample collection were utilised. Production was determined by multiplying weightspecific growth $(g)$ for each individual by its calculated in situ biomass $\left(\mu \mathrm{gC} \mathrm{m}^{-3}\right)$, given the sub-sample size and volume of water filtered. Annual production was derived for each species separately, except for Acartia spp. where all species were considered together, using trapezoidal integration between points. Total production was derived simply as the sum of production for each of the copepod species.
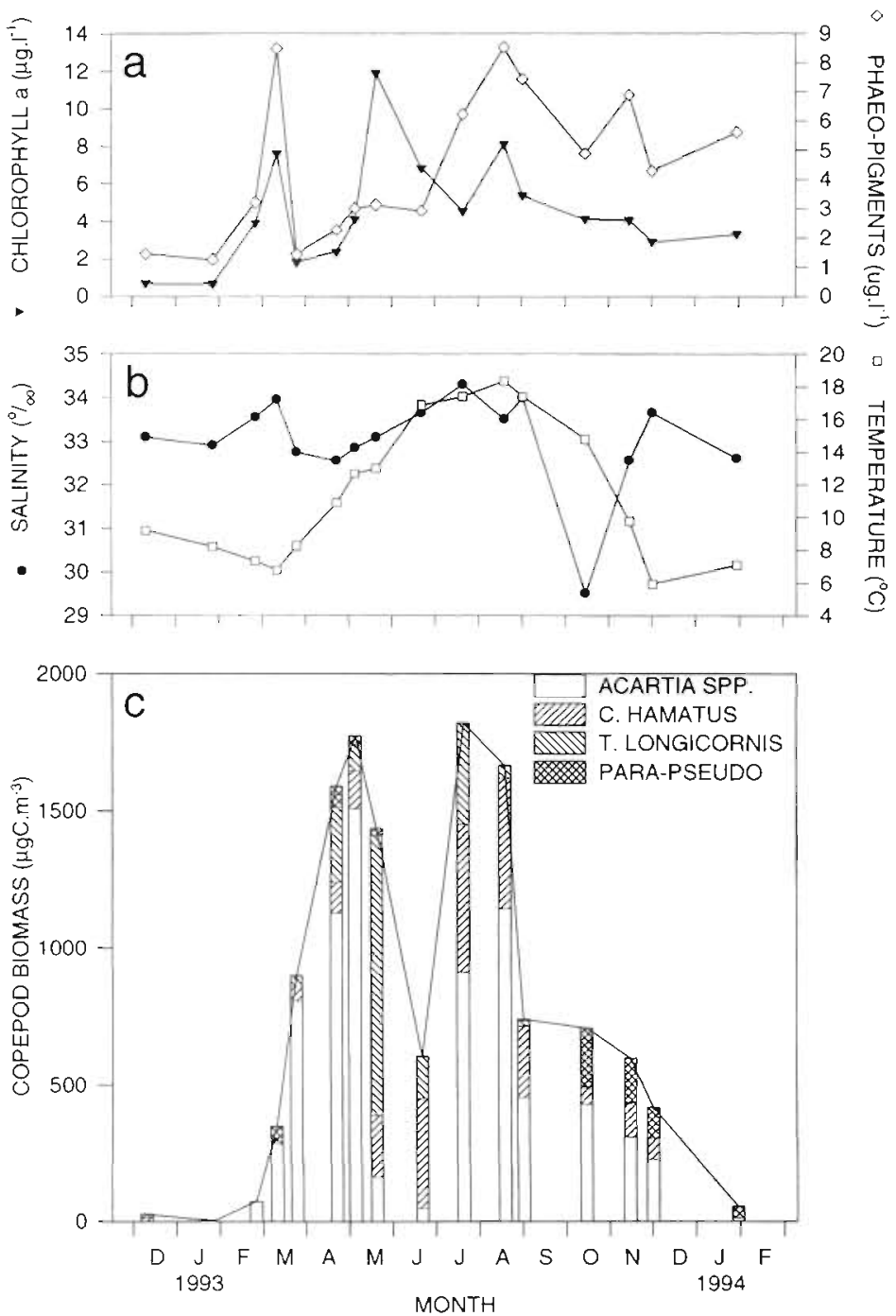

Fig. 2. Seasonal patterns at the Calshot site. (a) Chlorophyll a and phaeo-pigment concentrations; (b) temperature and salinity; and (c) biomass of copepods. Physical-chemical measurements are averages of values at 5 and $10 \mathrm{~m}$ depth

\section{RESULTS}

Temperature, salinity, chlorophyll a and phaeo-pigment measurements over the 14 mo investigation are presented in Fig. 2. Temperature shows a cyclical annual pattern with the highest temperatures recorded in midAugust at $18.4^{\circ} \mathrm{C}$, and the minimum at the beginning of December at $6.0^{\circ} \mathrm{C}$. Chlorophyll a peaked at $11.9 \mu \mathrm{g} \mathrm{l}^{-1}$ in May, and on only 3 occasions fell below $2 \mu \mathrm{g}^{-1}$, in December, January and April. Phaeo-pigments concentrations peaked in March at $>8 \mathrm{\mu g} \mathrm{l}^{-1}$, and also later in the year during August at $>8 \mu \mathrm{g} \mathrm{l}^{-1}$. October 1993 was a period of particularly heavy rainfall, and this explains the unusual low salinity (29.5\%) observed at the Calshot site. Salinity on all the other occasions it was measured was fairly stable, varying between 32.6 and $34.3 \%$. 


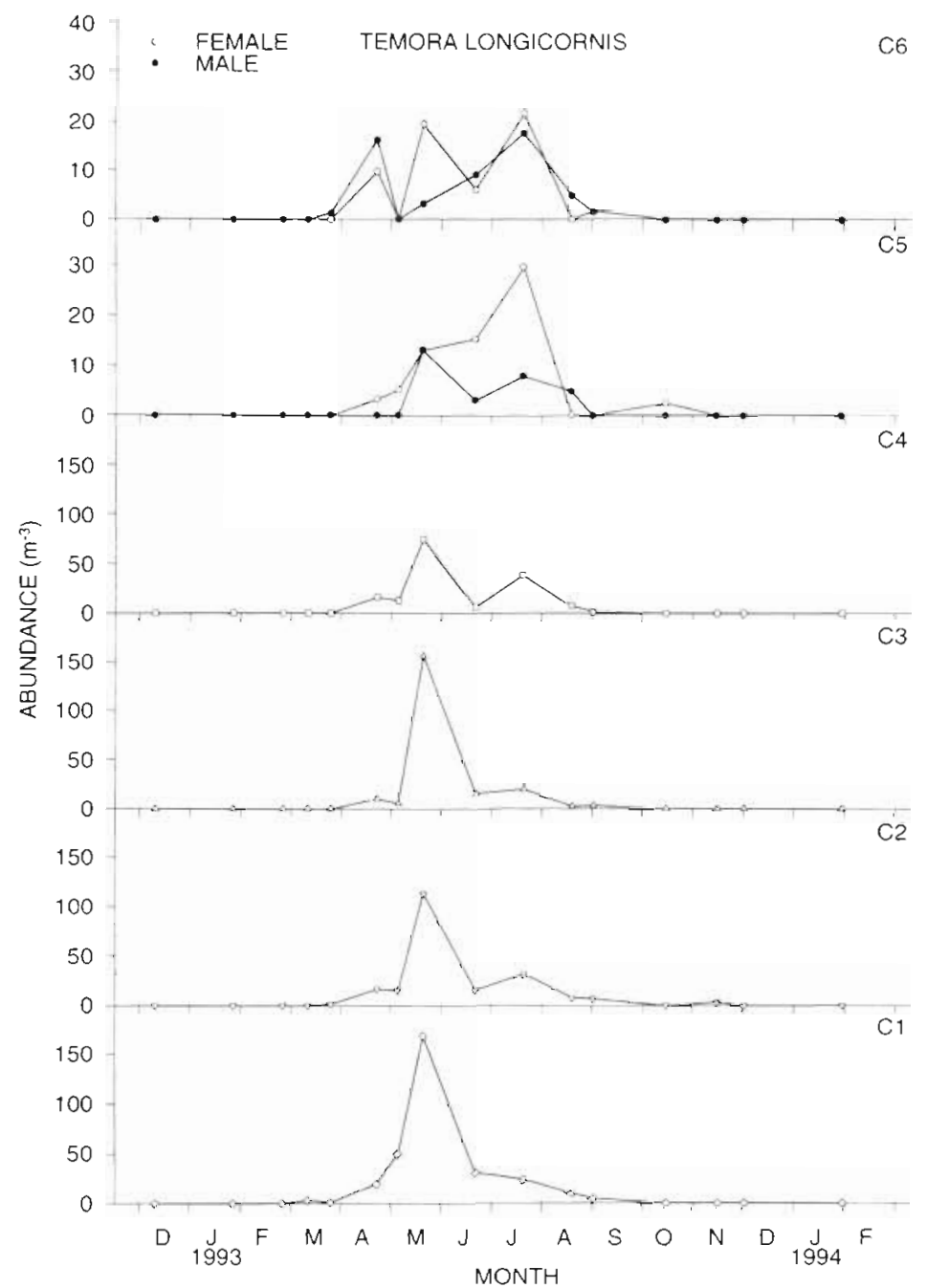

Fig. 3. Abundance of Temora longicornis (C1 to C6) over the 14 mo investigation (note scale change)

\section{Abundance patterns}

Abundances of copepodite stages over the $14 \mathrm{mo}$ investigation at Calshot are presented in Figs. 3 to 6. Although other calanoid copepod species not presented in detail here were occasionally present, these were always very rare, and their appearance sporadic. Temora longicornis was most abundant from April through to August, and typically absent during the winter months October to February (Fig. 3). Maximum concentrations of males and females were found in July when together they totalled $39 \mathrm{ind} . \mathrm{m}^{-3}$, C5 abundances also peaked at this point, while the densities of all the earlier copepodite stages peaked in May. Centropages hamatus copepodites were abundant from April until November, and rare or absent during the late winter and spring (Fig. 4).
Adult concentrations peaked in July at 53 ind. $\mathrm{m}^{-3}$. Abundances of stages generally fell rapidly after August, although abundance of C3s and C4s showed small secondary peaks in November. Acartia spp. were dominant throughout much of the year, with peaks in numbers during both April-May and July-August (Fig. 5). The peak in Acartia adult numbers occurred during April, this peak being predominantly A. bifilosa (Fig. 6). A. bifilosa was numerically the dominant Acartia adult during the first 5 mo of the year, with $A$. discaudata and $A$. clausi dominating from July until November-December. A. bifilosa adults reached abundances of almost 600 ind. $\mathrm{m}^{-3}$. A. clausi adults reached a maximum of 140 ind $\mathrm{m}^{-3}$ in July, while $A$. discaudata adults reached a maximum density of 166 ind. $\mathrm{m}^{-3}$ in August. A. margalefi were rare or absent throughout most of the year: the maximum abundance of adults occurred in May and August-September, although density never exceeded 18 ind. $\mathrm{m}^{-3}$. Paracalanus parvus adults were most abundant during November, when they reached 34 ind. $\mathrm{m}^{-3}$. Pseudocalanus elongatus adults were much rarer than $P$. parvus, and were recorded in November to January and in April. Maximum adult abundance of $P$. elongatus was just 10 ind. $\mathrm{m}^{-3}$ in January.

\section{Seasonal variations in size}

Mean prosome lengths for copepodites stages ( $\mathrm{C} 1$ to $\mathrm{C} 6$ ) of Temora longicornis decreased in all stages from a March to May maximum to a minimum in August to October (Fig. 7) There was a general absence of $T$ longicornis after September The pattern of change in length of Centropages hamatus was very similar to that for $T$. longicornis, with a decrease in size from spring (most values being highest in March to May) to summer and early autumn (the smallest individuals found in August to October). There was a general increase in size of $C$. hamatus after September, although not for C1 or C2. Copepodite stages $\mathrm{C} 1$ to $\mathrm{C} 5$ of Acartia spp. showed clear changes in mean prosome length, with increasing size from their first appearance in JanuaryFebruary until a minimum in March. After this peak, prosome lengths for all stages of this genera progressively decreased until September, when the minimum prosome length was recorded for all stages. Subsequently, mean prosome lengths generally increased 
once again. The older stages of all the species showed greater absolute size changes over the course of the investigation than the younger stages.

Acartia bifilosa adults demonstrated clear changes in mean prosome length (Fig. 8). Lengths increased from January to an annual maximum in March of $0.85 \mathrm{~mm}( \pm 0.027[ \pm \mathrm{SD}])$ and $0.87 \mathrm{~mm}( \pm 0.046)$ in males and females respectively. After this, prosome lengths decreased until July, when female lengths were the shortest recorded, but no males were found. A. bifilosa adults were absent after July until their re-appearance in November and December when their lengths were close to, but lower than, those recorded during the previous winter. A. discaudata adult prosome lengths were highest for males in April to May, after which they were only recorded again in mid-July, when their size had decreased dramatically to $0.63 \mathrm{~mm}( \pm 0.016)$ in females and $0.63 \mathrm{~mm}( \pm 0.005)$ in males. From September until December size increased in both sexes. In $A$. clausi size was fairly constant from July to October, with mean prosome lengths of females ranging from $0.79 \mathrm{~mm}$ $( \pm 0.052)$ to $0.81 \mathrm{~mm}( \pm 0.039)$, and for males between $0.75( \pm 0.022)$ and $0.78 \mathrm{~mm}( \pm 0.020)$. Following this period of stability, the mean prosome length increased into winter. A single large female of $1.0 \mathrm{~mm}$ prosome length was found in May 1993. The sporadic appearance and scarcity of $A$. margalefi adults made it impossible to describe the seasonal trend. Prosome lengths never exceeded $0.60 \mathrm{~mm}$ in this species, and means were as low as 0.52 $\mathrm{mm}( \pm 0.042)$ in females and $0.54 \mathrm{~mm}( \pm 0.034)$ in males during September.

Comparisons of prosome lengths with temperature were made using correlation analysis on data collected on the same date. As lengths and weights of the older stages of copepods depend on their temperature history, analysis was also carried out regressing prosome length against temperature measured on the previous sampling date (i.e. typically 2 or 4 wk before). Correlations between concurrent temperature and prosome length data were not significant $(p>0.05)$ in all cases for all stages and sexes (Table 1), although in many cases there were significant relationships. In all cases where the relationship was significant the slope was negative, i.e. mean prosome length decreased with increasing temperature. Often the relationship between prosome length and temperature on the previous sampling occasion was more highly significant than the relationship with the concurrent temperature.

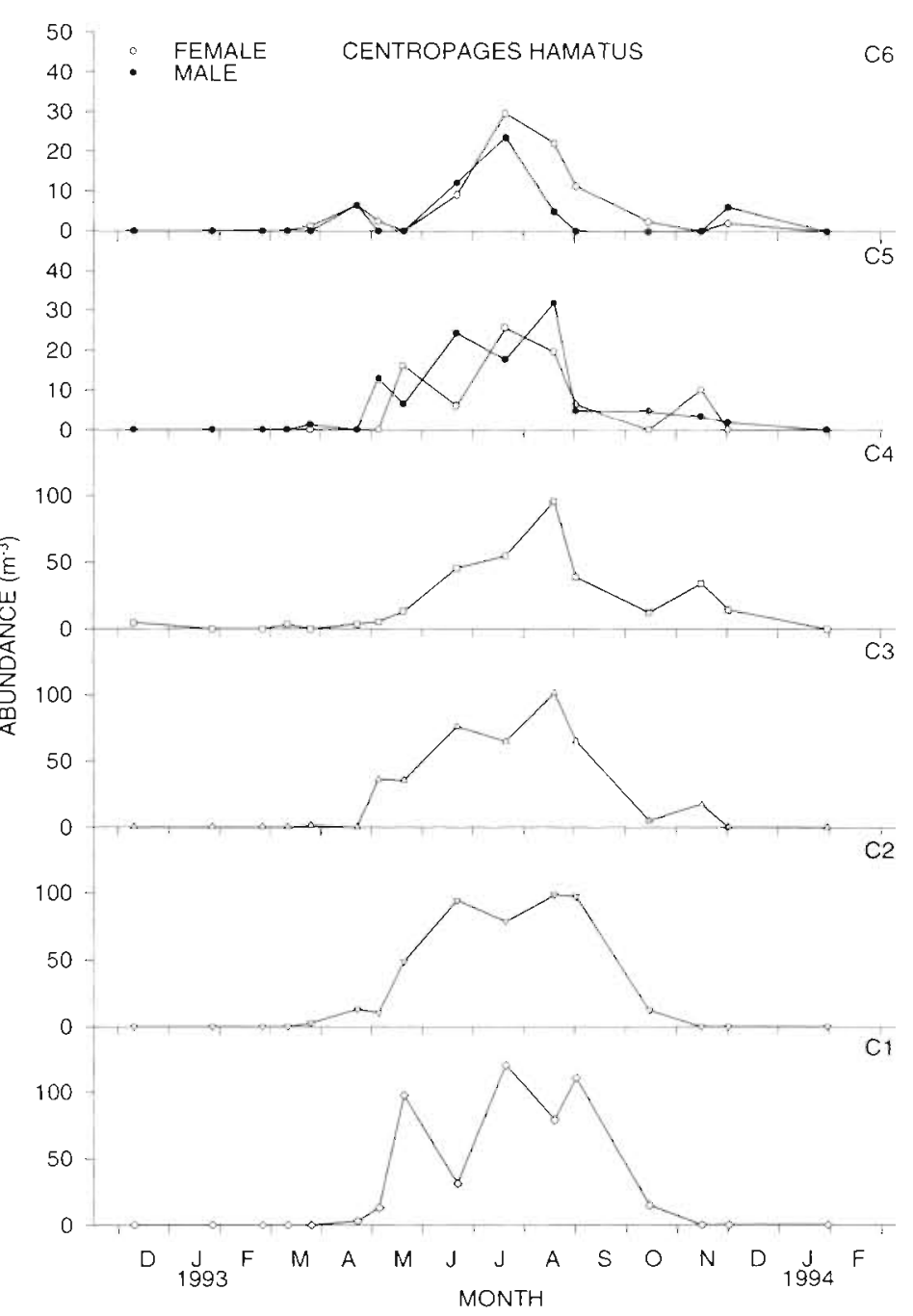

Fig. 4. Abundance of Centropages hamatus ( $\mathrm{C} 1$ to $\mathrm{C} 6$ ) over the 14 mo investigation (note scale change)

\section{Biomass and production}

Acartia spp. was the single most dominant group in terms of biomass throughout much of the year (Fig. 2c), typically having greater biomass than all the other calanoids together. The Para-Pseudocalanus group and Centropages hamatus had higher biomass than Acartia spp. in winter, and the biomass of C. hamatus, and also Temora longicornis, was higher in May and June. Acartia biomass was at its highest in early May when it reached $1508 \mu \mathrm{gC} \mathrm{m}^{-3}$, and in August when it reached $1144 \mu \mathrm{gC} \mathrm{m}^{-3}$. C. hamatus biomass increased from February, when no individuals were found, to the end of July when its biomass reached its maximum at $541 \mathrm{\mu gC} \mathrm{m}^{-3}$. There were 3 discrete peaks of $T$. longicornis biomass, in April $\left(273 \mu \mathrm{gC} \mathrm{m}^{-3}\right)$, in May $\left(1021 \mathrm{\mu gC} \mathrm{m}^{-3}\right)$ and in July $\left(365 \mu \mathrm{gC} \mathrm{m}^{-3}\right)$. ParaPseudocalanus biomass was highest in October, at 


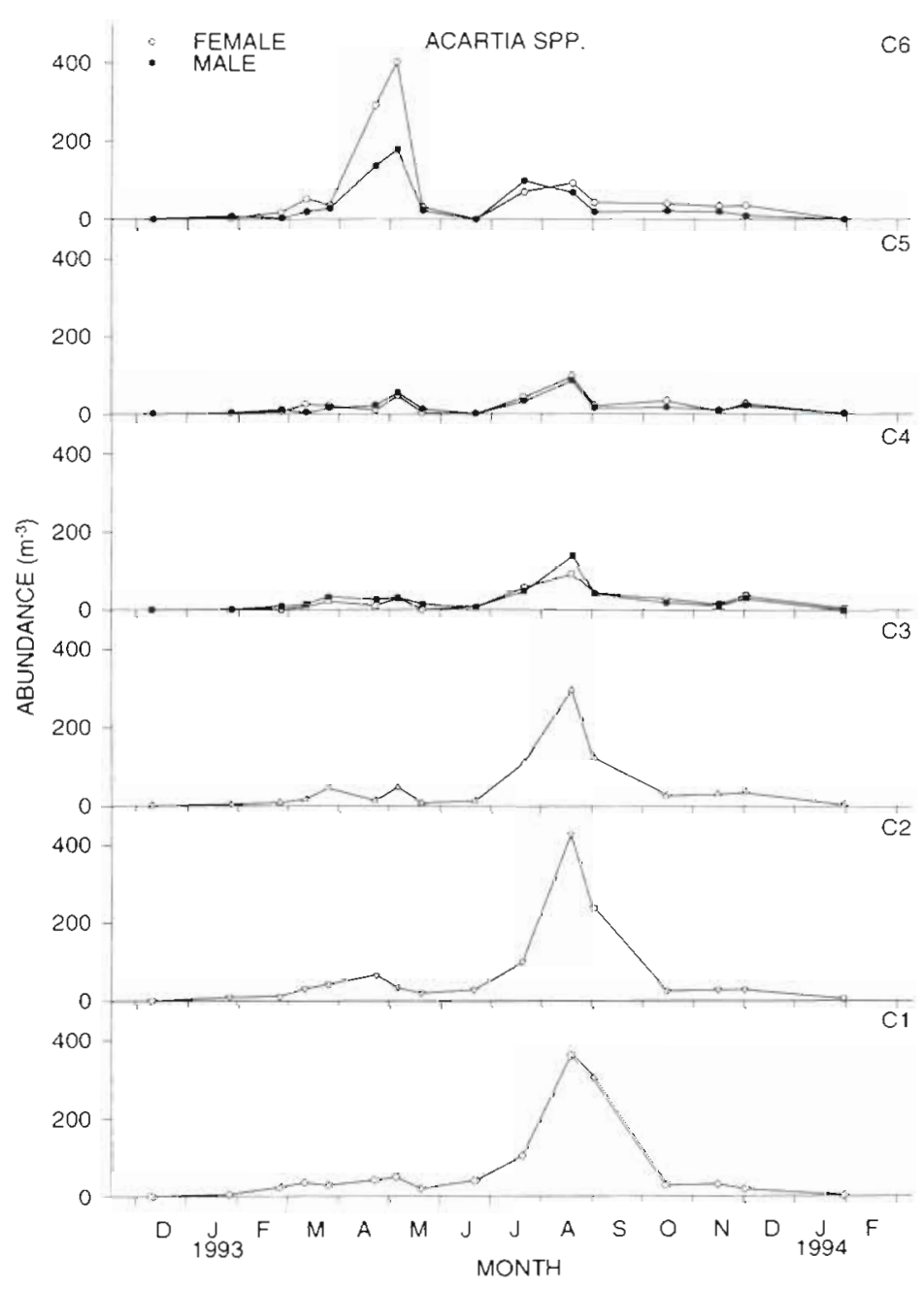

Fig. 5. Abundance of Acartia spp. (C1 to C6) over the 14 mo investigation

$215 \mu \mathrm{gC} \mathrm{m}^{-3}$. Total calanoid copepod biomass was lowest in January at $<1 \mu \mathrm{gC} \mathrm{m}^{-3}$, then increased until May when it reached $1772 \mu \mathrm{gC} \mathrm{m}^{-3}$. There was a subsequent fall, with a mid-year low in June, after which it rose once again reaching $1818 \mu \mathrm{gC} \mathrm{m}^{-3}$ in July. Although biomass fell after this point values were above $400 \mu \mathrm{gC} \mathrm{m}^{-3}$ until after early December 1993.

The contribution of each of the calanoid copepods to the total annual production varied dramatically (Fig. 9 , Table 3), and was predominantly a reflection of their total biomass dominance. Acartia spp. had the highest annual production of $17.62 \mathrm{mgC} \mathrm{m}^{-3} \mathrm{yr}^{-1}$, Centropages hamatus had an annual production of $8.16 \mathrm{mgC} \mathrm{m}^{-3}$ $\mathrm{yr}^{-1}$, while Temora longicornis had an annual rate of $4.77 \mathrm{mgC} \mathrm{m}^{-3} \mathrm{yr}^{-1}$ The Paracalanus parvus and Pseudocalanus elongatus group had the smallest contribution at $1.67 \mathrm{mgC} \mathrm{m}^{-3} \mathrm{yr}^{-1}$. The sum of these components gave a total annual production by the calanoid copepods of $32.2 \mathrm{mgC} \mathrm{m}^{-3} \mathrm{yr}^{-1}$.

\section{DISCUSSION}

\section{Abundance patterns}

In the present investigation calanoid numbers and biomass at the Calshot site were dominated by just 7 species; Acartia clausi, A. bifilosa, A. tonsa, Centropages hamatus, Temora longicornis, Paracalanus parvus and Pseudocalanus elongatus. Although there has been some confusion over the morphology and classification of $A$. bifilosa and its varieties, the description of the individuais from this area has been documented by Hirst \& Castro-Longoria (1998) as part of a detailed examination of its classification.

Acartia tonsa accounted for up to $4 \%$ of the total Acartia population abundance at a single point in time at Calshot in a previous study (Conover 1957). It was not found during the present study, but it is still found in reduced salinity areas of the river Test (Castro-Longoria 1998). Its sporadic appearance may be the result of inter-annual changes in physical parameters such as temperature and salinity, or the degree of estuarine flushing. As A. margalefi is morphologically similar to A. clausi, and was only described recently by Alcaraz (1976), it is not surprising that it was not reported in this area until the 1990s (Castro-Longoria \& Williams 1996). When both of these species occurred together here, A. margalefi always had a mean prosome length between $66 \%$ and $72 \%$ that of $A$. clausi, this was one of the most obvious differences between the 2 species.

Of the Acartia species, A. bifilosa was numerically dominant during January to May; $A$. discaudata and $A$. clausi were co-dominant from July to September, and then $A$. clausi was dominant until December (with $A$. discaudata still the second most abundant). After December A. discaudata became dominant (Fig. 6). The successional pattern described by Conover (1957) during October 1954 to June 1955, for a site at the entrance to Southampton Water, was similar to that found in the present investigation. Conover (1957) found $A$. clausi and $A$. discaudata were the co-dominant Acartia species over the winter months of November to January, after which $A$. bifilosa became dominant. From May, A. clausi was again the most abundant Acartia species. It is of interest to compare our results with those of Raymont \& Carrie (1964) collected in the $1950 \mathrm{~s}$, at a site not more than $2.5 \mathrm{~km}$ from the current site, using a pump and hose system with screening onto a No. 10 nylon net (i.e. $135 \mu \mathrm{m}$ meshi 

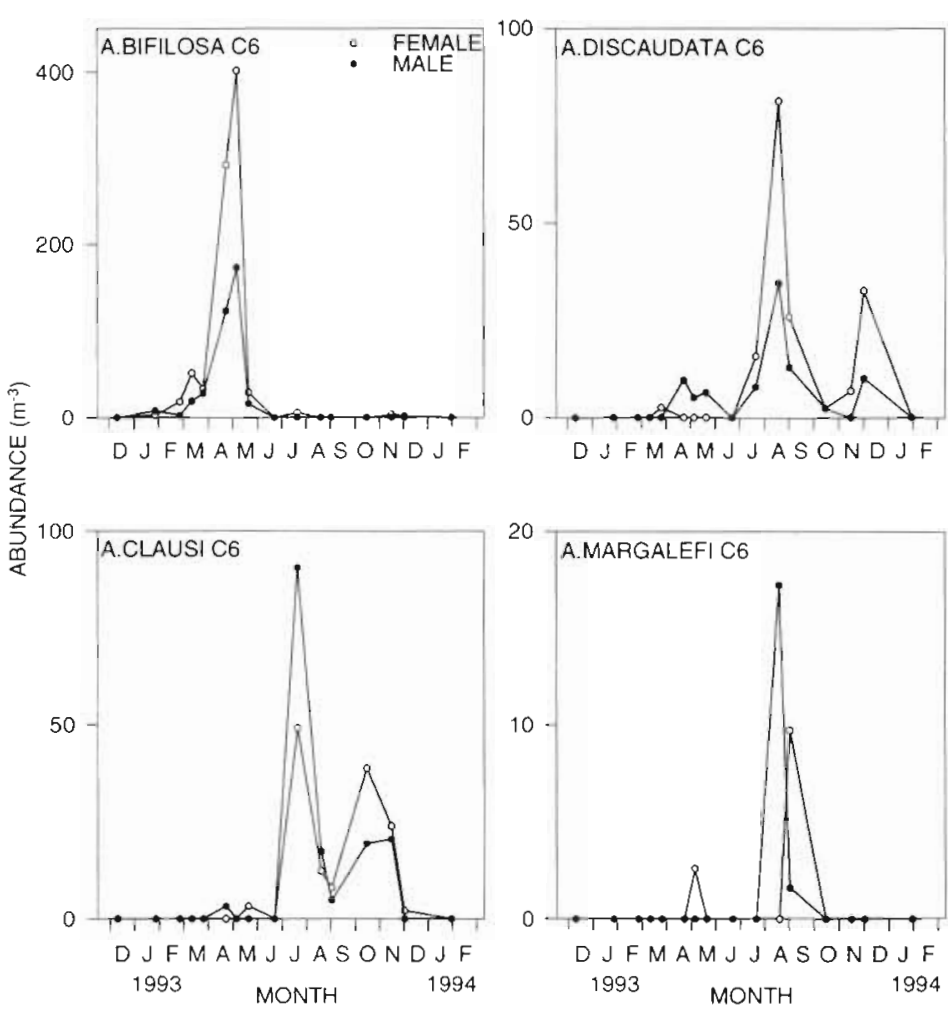

Fig. 6. Abundance of the adult Acartia species found at the Calshot site (note scale change)

Heinle 1966). They reported that Centropages hamatus was the most dominant calanoid after the Acartia group. This species was reported as rare before March-April, but moderately common from May and throughout the summer. It was described as generally persisting through the autumn, and disappearing in late December. This pattern is similar to that found in the present investigation; the species was the most abundant after Acartia spp. Temora longicornis was found by Raymont \& Carrie (1964) to be less common than $C$. hamatus at Calshot, and to be more restricted in timing, not appearing until April and then being plentiful until August. It was also much less common than $C$. hamatus in the autumn. Again this situation is similar to that found in the current study, with $T$. longicornis appearing in April; it was more abundant than C. hamatus in May, but after this the latter became more abundant. They also found Paracalanus parvus and Pseudocalanus elongatus to be sporadic in appearance at Calshot, the former species being more abundant than the latter. $P$. parvus was also found in greater densities than $P$. elongatus in the present investigation, and their appearance was certainly variable. Raymont \& Carrie (1964) observed greater peak densities of calanoids over the $6 \mathrm{yr}$ of their study than those found in the present investigation. They report spring maxima of around 2000 to 2500 ind. $\mathrm{m}^{-3}$ in 1954,1957 and 1959, but 5000 ind $\mathrm{m}^{-3}$ in 1956 and 1958. In 1993 the calanoid peak in spring was 1065 ind. $\mathrm{m}^{-3}$, with maximum annual numbers in August of 2155 ind. $\mathrm{m}^{-3}$. Raymont \& Carrie (1964) found mean densities of calanoids between September and December to vary between 433 and 1263 ind. $\mathrm{m}^{-3}$; in the present investigation average calanoid copepodite numbers during the same period fell between this range at 900 ind $\mathrm{m}^{-3}$.

\section{Seasonal variations in size}

Seasonal variations in size and weight have often been recorded in marine invertebrates including copepods. Copepod body sizes, as in the current investigation, are usually inversely related to temperature in nature (Uye et al. 1982, Liang \& Uye 1996). Regressions of prosome lengths, for each separate stage and sex, against temperature were carried out for each of the species at Calshot. Previously, such relationships have been reported to be more marked in older stages (see Uye et al. 1982, Jerling \& Wooldridge 1991, Liang \& Uye 1996, Liang et al. 1996), and seasonal changes in prosome length in the current investigation were also greater in many of the older stages, although for Acartia bifilosa and A. clausi, neither adult females nor males showed a significant relationship between prosome length and temperature. Changes in body size of copepods may also be positively related to food concentration (Moraitou-Apostolopoulou 1975, Landry 1978, Evans 1981, Durbin et al. 1983, Berggreen et al. 1988, Christou \& Verriopoulos 1993). In Southampton Water, as chlorophyll a concentrations change dramatically on a very short time scale (Kifle 1992), the changes of prosome length with chlorophyll concentration were not examined here, as these were believed not to accurately reflect any real relationships given our sampling frequency

\section{Pelagic carbon flux}

The values for calanoid copepod production (32.2 $\mathrm{mgC} \mathrm{m}^{-3} \mathrm{yr}^{-1}$ ) are included together with previous estimates of bacterial, ciliate, and size-fractioned primary production for the Calshot site in a carbon flow diagram (Fig. 9). Primary production was measured at the Calshot site from April to October 1990 using a $C^{14}$ incubation technique (Iriarte \& Purdie 1994), and a total annual rate of $6667 \mathrm{mgC} \mathrm{m}^{-3} \mathrm{yr}^{-1}$ was derived. 

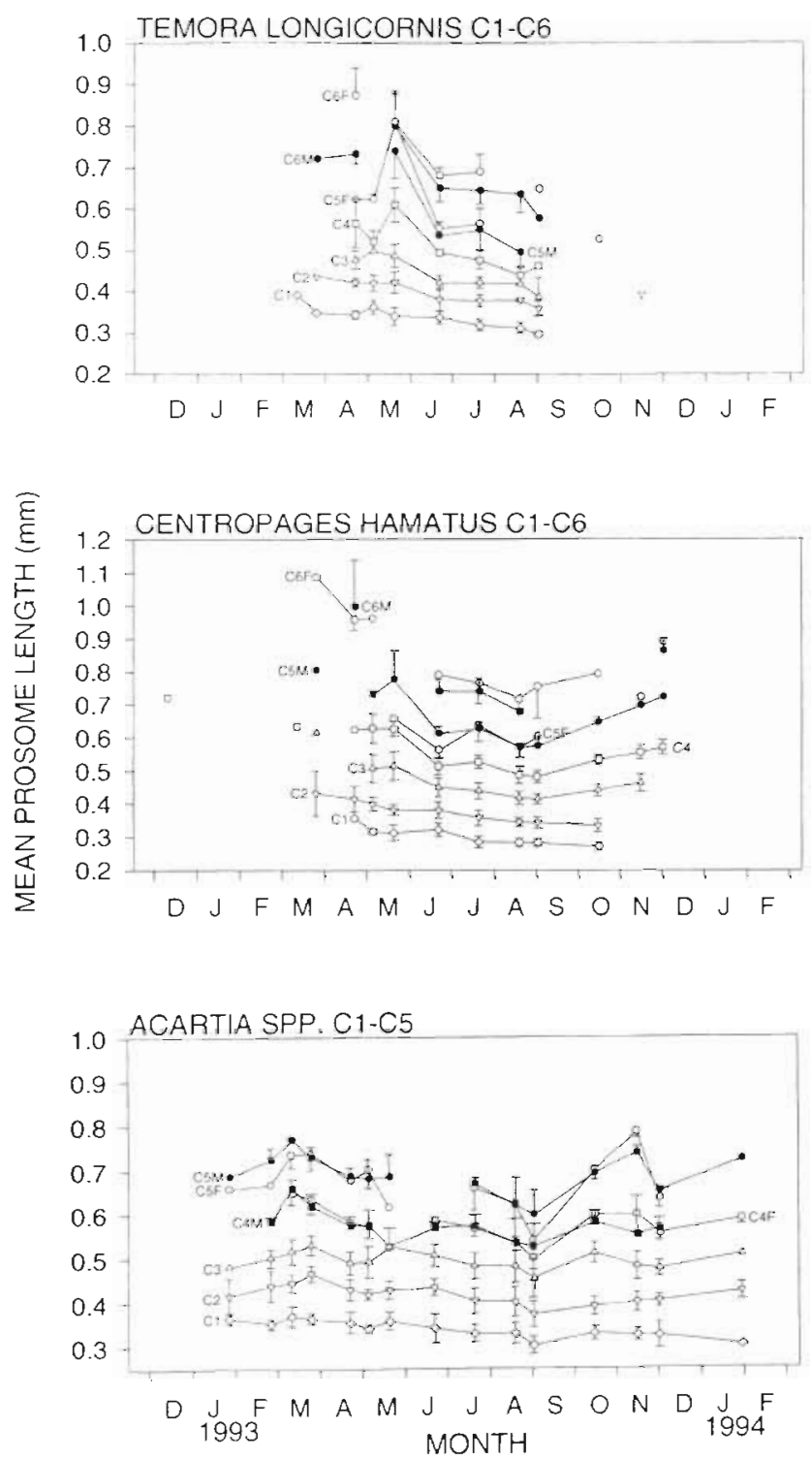

Fig. 7. Mean prosome lengths of Temora longicornis ( $\mathrm{C} 1$ to C6), Centropages hamatus ( $\mathrm{C} 1$ to $\mathrm{C} 6$ ) and Acartia spp. (C1 to C5) over the 14 mo investigation. Error bars give standard deviation of measurements lines joining symbols are only given when individuals were found in consecutive samples

Annual bacterial production was measured at Calshot from January 1987 to January 1988, and is given as $8300 \mathrm{mgC} \mathrm{m}^{-3} \mathrm{yr}^{-1}$ (Antai 1989). The bacterial production, which exceeds primary production, may be met by additional allochthonous inputs, with a potential supply from terrestrial inputs as well as from lateral movements of material of marine or estuarine origins. Material may also recycle through the bacterial compartment so as to inflate the bacterial production value with respect to primary production. Estimates of the mean annual production of heterotrophic ciliates at

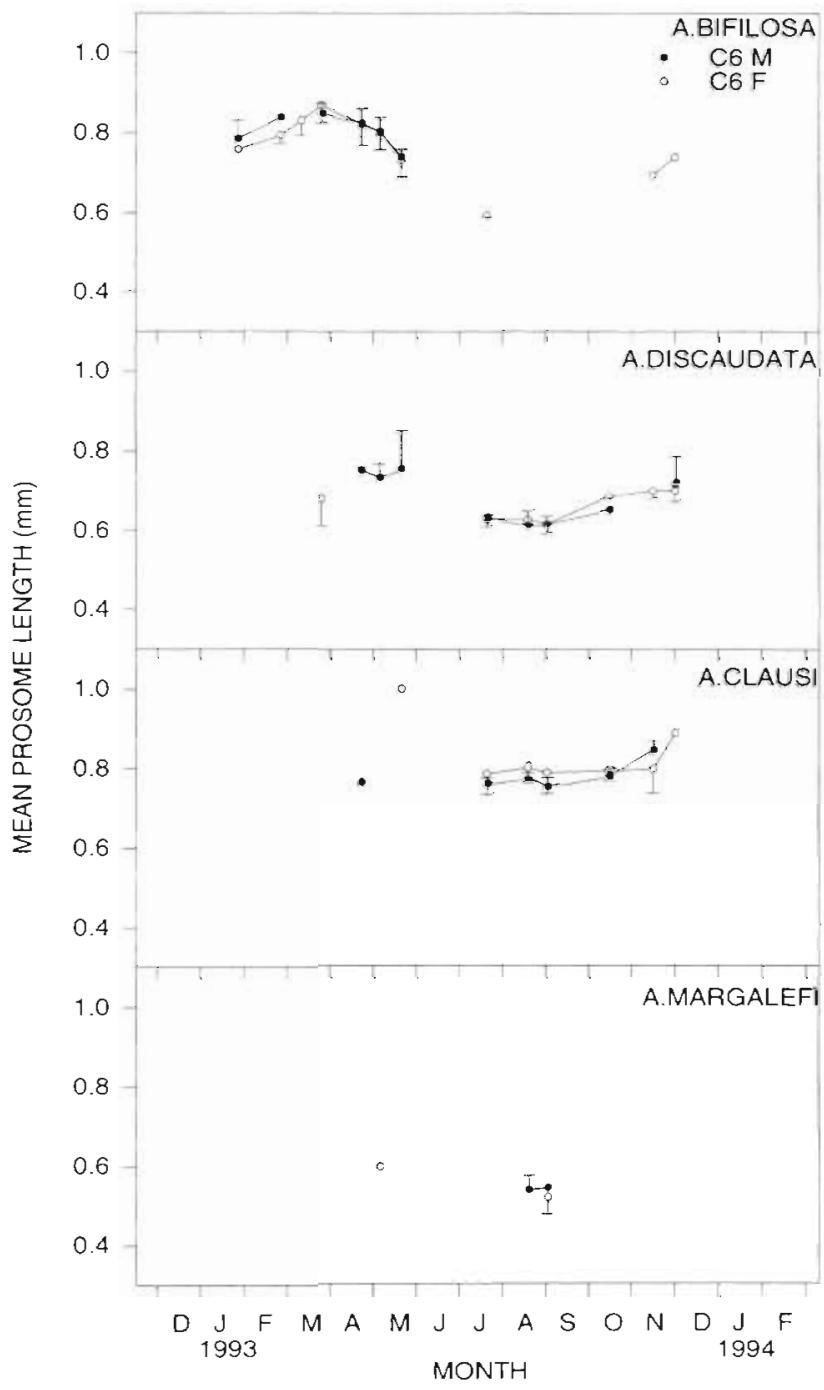

Fig. 8. Mean prosome length measurements for adult males and females of each Acartia species during the 14 mo investigation. Error bars represent standard deviation of measurements, lines linking symbols are only given when individuals were found in consecutive samples

this location were derived by Leakey et al. (1992) for the penod June 1986 to January 1987, using an equation that predicts ciliate growth from individual size and temperature (i.e. Montagnes et al. 1988). We have estimated the ingestion demand of ciliates from their production by assuming a gross growth efficiency (GGE) of 30\% (Straile 1997). Similarly, annual ingestion demand by the copepods was derived assuming for this group a GGE of $26 \%$ (Straile 1997). This efficiency may be too high given the conditions in the estuary, where sediment and detritus concentrations are elevated.

Combining production estimates for various components collected over several years has the disadvan- 
Table 1. Regression analysis of mean prosome length versus concurrent temperature and versus temperature on the previous sampling occasion. Equations are only given where the relationship is significant $(p<0.05)$. $n$ is the number of observations, PL is the prosome length $(\mathrm{mm}), \mathrm{T}$ is temperature $\left({ }^{\circ} \mathrm{C}\right)$. ns: not significant

\begin{tabular}{|c|c|c|c|c|c|c|c|c|}
\hline \multirow[t]{2}{*}{ Species/stage } & \multicolumn{4}{|c|}{ Concurrent temperature $\left({ }^{\circ} \mathrm{C}\right)$} & \multicolumn{4}{|c|}{ Previous temperature $\left({ }^{\circ} \mathrm{C}\right)$} \\
\hline & $\mathrm{n}$ & $\mathrm{r}^{2}$ & $\mathrm{p}$ & Equation & $\mathrm{n}$ & $r^{2}$ & $\mathrm{p}$ & Equation \\
\hline \multicolumn{9}{|l|}{ Acartia spp. } \\
\hline $\mathrm{C} 1$ & 15 & 0.111 & ns & - & 14 & 0.180 & ns & - \\
\hline $\mathrm{C} 2$ & 15 & 0.250 & ns & - & 14 & 0.573 & $<0.01$ & $P L=0.4694-0.0044 T$ \\
\hline $\mathrm{C} 3$ & 15 & 0.086 & ns & - & 14 & 0.236 & ns & - \\
\hline $\mathrm{C} 4 \mathrm{~F}$ & 12 & 0.348 & $<0.05$ & $P L=0.6435-0.0052 \mathrm{~T}$ & 12 & 0.433 & $<0.05$ & $P L=0.6502-0.0058 \mathrm{~T}$ \\
\hline $\mathrm{C} 4 \mathrm{M}$ & 13 & 0.334 & $<0.05$ & $\mathrm{PL}=0.6314-0.0048 \mathrm{~T}$ & 13 & 0.398 & $<0.05$ & $\mathrm{PL}=0.6401-0.0056 \mathrm{~T}$ \\
\hline $\mathrm{C} 5 \mathrm{~F}$ & 1.3 & 0.234 & ns & - & 12 & 0.324 & ns & - \\
\hline $\mathrm{C} 5 \mathrm{M}$ & 14 & 0.478 & $<0.01$ & $\mathrm{PL}=0.7720-0.0074 \mathrm{~T}$ & 13 & 0.545 & $<0.01$ & $\mathrm{PL}=0.7806-0.0079 \mathrm{~T}$ \\
\hline \multicolumn{9}{|l|}{ Acartia bifilosa } \\
\hline $\mathrm{C} 6 \mathrm{~F}$ & 10 & 0.384 & ns & - & 9 & 0.836 & $<0.001$ & $\mathrm{PL}=1.0122-0.0244 \mathrm{~T}$ \\
\hline $\mathrm{C} 6 \mathrm{M}$ & 6 & 0.424 & ns & - & 5 & 0.922 & $<0.01$ & $P L=0.9740-0.01761$ \\
\hline \multicolumn{9}{|c|}{ Acartia discaudata } \\
\hline $\mathrm{C} 6 \mathrm{~F}$ & 7 & 0.757 & $<0.05$ & $\mathrm{PL}=0.7473-0.0064 \mathrm{~T}$ & 7 & 0.535 & ns & - \\
\hline C6M & 8 & 0.592 & $<0.05$ & $\mathrm{PL}=0.8396-0.0114 \mathrm{~T}$ & 8 & 0.830 & $<0.01$ & $\mathrm{PL}=0.8759-0.0139 \mathrm{~T}$ \\
\hline \multicolumn{9}{|l|}{ Acartia clausi } \\
\hline $\mathrm{C} 6 \mathrm{~F}$ & 7 & 0.182 & ns & - & 7 & 0.287 & ns & - \\
\hline C6M & 6 & 0.445 & ns & - & 6 & 0.200 & ns & - \\
\hline \multicolumn{9}{|c|}{ Centropages hamatus } \\
\hline C1 1 & 8 & 0.500 & $<0.05$ & $\mathrm{PL}=0.4155-0.0074 \mathrm{~T}$ & 8 & 0.913 & $<0.001$ & $\mathrm{PL}=0.4098-0.0074 \mathrm{~T}$ \\
\hline $\mathrm{C} 2$ & 9 & 0.737 & $<0.01$ & $\mathrm{PL}=0.4983-0.0085 \mathrm{~T}$ & 9 & 0.974 & $<0.001$ & $\mathrm{PL}=0.4826-0.0079 \mathrm{~T}$ \\
\hline C3 & 9 & 0.767 & $<0.01$ & $\mathrm{PL}=0.6813-0.0145 \mathrm{~T}$ & 9 & 0.780 & $<0.01$ & $P L=0.6702-0.0143 \mathrm{~T}$ \\
\hline $\mathrm{C} 4$ & 12 & 0.474 & $<0.05$ & $\mathrm{PL}=0.7230-0.0116 \mathrm{~T}$ & 11 & 0.670 & $<0.05$ & $P L=0.7176-0.0120 \mathrm{~T}$ \\
\hline C5F & 6 & 0.806 & $<0.05$ & $\mathrm{PL}=0.8732-0.0161 \mathrm{~T}$ & 6 & 0.355 & ns & - \\
\hline C5M & 10 & 0.640 & $<0.01$ & $\mathrm{PL}=0.8798-0.0152 \mathrm{~T}$ & 10 & 0.714 & $<0.01$ & $\mathrm{PL}=0.9101-0.0175 \mathrm{~T}$ \\
\hline $\mathrm{C} 6 \mathrm{~F}$ & 9 & 0.651 & $<0.01$ & $\mathrm{PL}=1.1625-0.0224 \mathrm{~T}$ & 9 & 0.843 & $<0.001$ & $\mathrm{PL}=1.1945-0.0255 \mathrm{~T}$ \\
\hline $\mathrm{C} 6 \mathrm{M}$ & 5 & 0.561 & ns & - & 5 & 0.835 & $<0.01$ & $\mathrm{PL}=1.1752-0.0284 \mathrm{~T}$ \\
\hline \multicolumn{9}{|c|}{ Temora longicornis } \\
\hline $\mathrm{C} 1$ & 9 & 0.712 & $<0.01$ & $\mathrm{PL}=0.4151-0.0056 \mathrm{~T}$ & 9 & 0.724 & $<0.01$ & $\mathrm{PL}=0.4067-0.0054 \uparrow$ \\
\hline $\mathrm{C} 2$ & 9 & 0.647 & $<0.01$ & $\mathrm{PL}=0.4797-0.0058 \mathrm{~T}$ & 9 & 0.748 & $<0.01$ & $\mathrm{PL}=0.4729-0.0057 \mathrm{~T}$ \\
\hline C3 & 7 & 0.792 & $<0.01$ & $\mathrm{PL}=0.6398-0.0128 \mathrm{~T}$ & 7 & 0.685 & $<0.05$ & $\mathrm{PL}=0.5753-0.0094 \mathrm{~T}$ \\
\hline $\mathrm{C} 4$ & 7 & 0.738 & $<0.05$ & $\mathrm{PL}=0.7798-0.0177 \mathrm{~T}$ & 7 & 0.560 & ns & - \\
\hline C5F & 6 & 0.251 & ns & - & 6 & 0.154 & ns & - \\
\hline $\mathrm{C} 5 \mathrm{M}$ & 4 & 0.780 & $<0.05$ & $\mathrm{PL}=1.3331-0.0459 \mathrm{~T}$ & 4 & 0.436 & ns & - \\
\hline $\mathrm{C} 6 \mathrm{~F}$ & 5 & 0.976 & $<0.01$ & $\mathrm{PL}=1.2226-0.0318 \mathrm{~T}$ & 5 & 0.773 & $<0.05$ & $\mathrm{PL}=1.0375-0.0213 \mathrm{~T}$ \\
\hline $\mathrm{C} 6 \mathrm{M}$ & 7 & 0.522 & ns & - & 7 & 0.486 & ns & - \\
\hline
\end{tabular}

tage that there may be inter-annual variability in the production of individual components, but this method provides a first step towards assessing the possible general importance of each of the compartments. The likely ingestion food sources for the copepods are algae $>3 \mu \mathrm{m}$, detrital material, allochthonous inputs and ciliates. The ingestion demand of the copepods was $2.2 \%$ of the production by the $>3 \mu \mathrm{m}$ algae, while the ingestion demand of ciliates was almost 60 times greater, at $110 \%$ of total primary production. This suggests ciliates may have met their demands by ingesting material which was allochthonous to the site, although production and ingestion demands for ciliates were probably too high, because the equation of Montagnes et al. (1988) used to estimate growth was derived under conditions where food was not limiting This may not always accurately reflect the situation in the natural environment

Annual size fractioned primary production estimates, together with ciliate, tintinnid, bacterial and copepod production values for other shallow nearshore locations with water column depths $<200 \mathrm{~m}$ are compiled in Table 2. These previous investigations have shown copepod annual production to be typically lower than that of ciliates (but not Uye \& Shimazu 1997), although the 2 values are usually within an order of magnitude of one another, i.e. in the Gulf of Maine, USA (Montagnes et al. 1988), Lime Cay, Jamaica (Roff et al. 1990), and the Southern Kattegat (Kiørboe \& Nielsen 1994, Nielsen \& Kiørboe 1994). The present study is unusual in that copepod annual production and ingestion demand are very much lower 


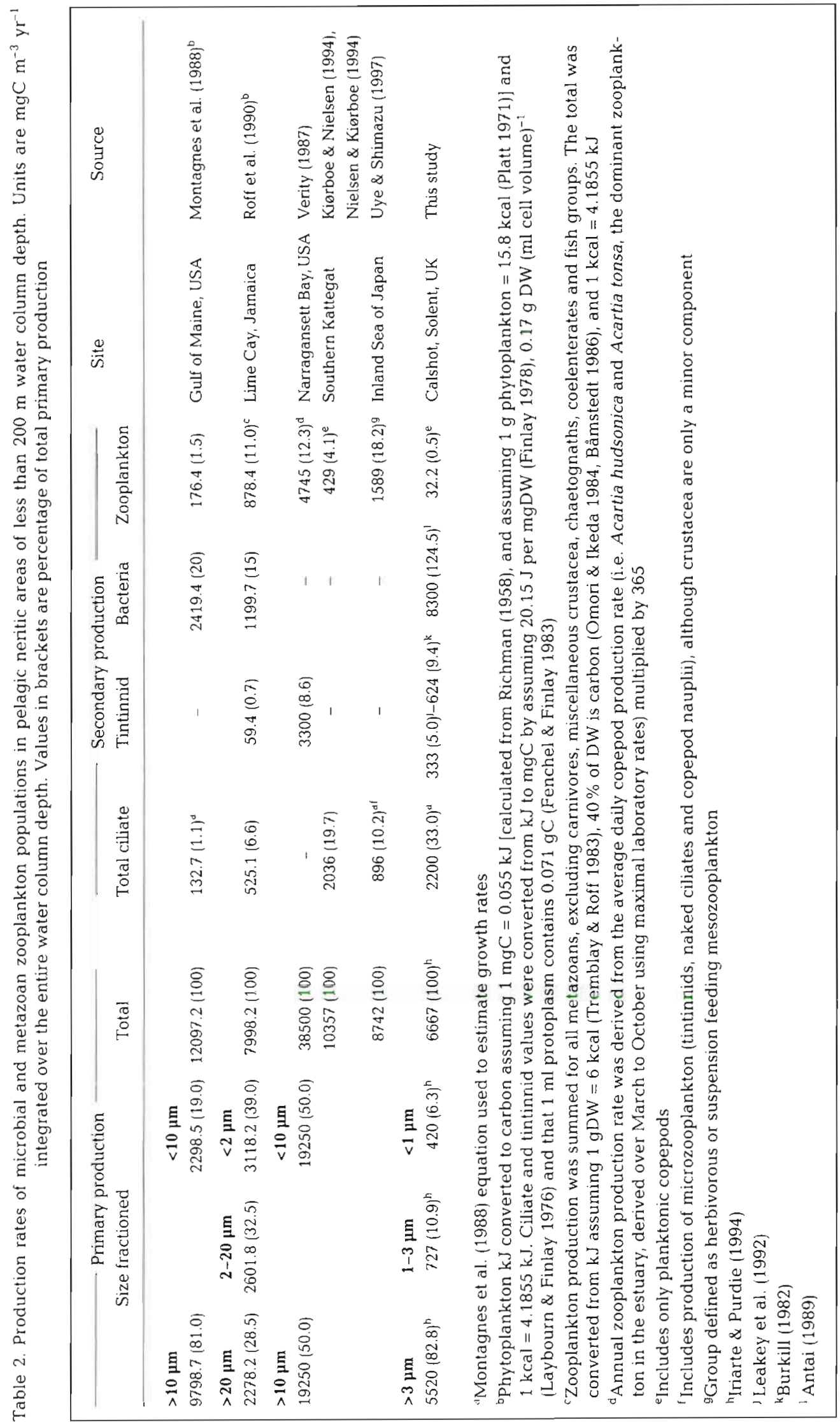




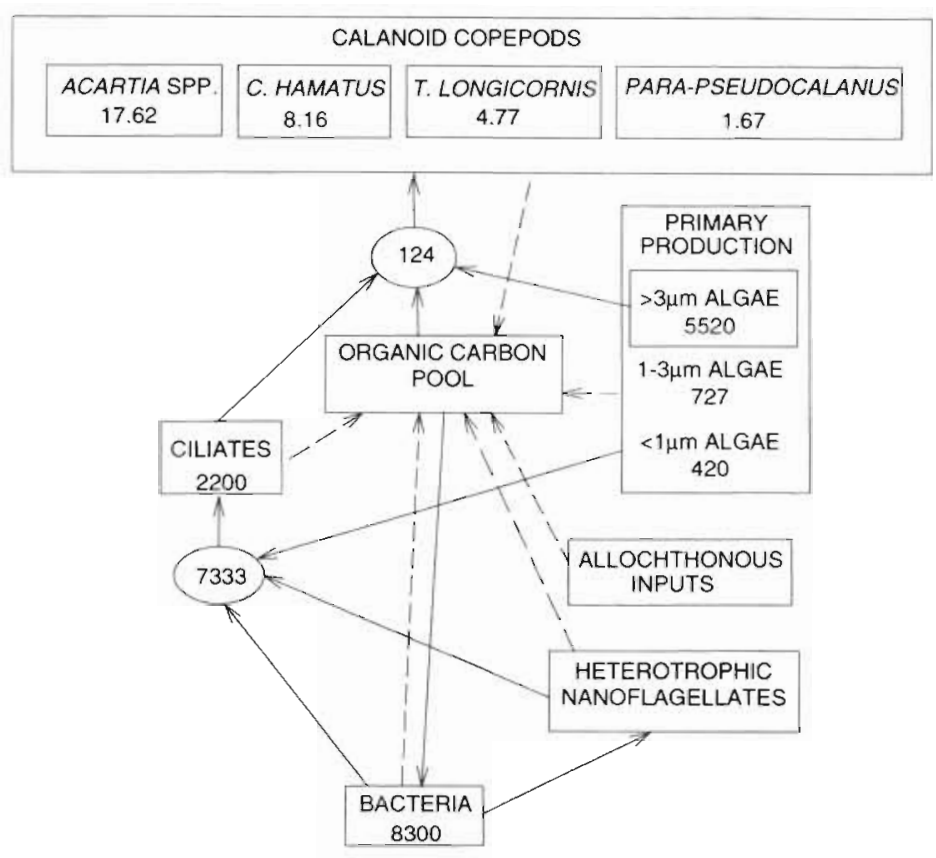

Fig. 9. Pelagic carbon flux through the biological community at the Calshot site; all values are integrated over the entire water column depth. Values in boxes are production estimates, those in ellipses are ingestion demands (units: $\mathrm{mgC} \mathrm{m}^{-3} \mathrm{yr}^{-1}$ ). Solid arrows represent ingestion of carbon; dashed arrows represent movement to a non-living organic carbon 'pool'

than those of the ciliates. In the other shallow water neritic studies, annual production by copepods was between 21 and $177 \%$ that of the ciliates, while at Calshot the proportion was only $1.5 \%$. Copepod secondary production as a percentage of total primary production is also relatively low at the Calshot site, $0.5 \%$. In the other studies compiled here, this value was between 1.5 and $18.2 \%$. A great many investigations of neritic and coastal water copepod production have demonstrated rates in excess of 100 to $1000 \mathrm{mgC}$ $\mathrm{m}^{-3} \mathrm{yr}^{-1}$ when integrated over total water column depth (e.g. Landry 1978, Uye 1982, Kimmerer \& McKinnon 1987, Uye et al. 1987, Roff et al. 1988, McLaren et al. 1989, Chisholm \& Roff 1990, Jerling \& Wooldridge 1991, Kiørboe \& Nielsen 1994, Escaravage \& Soetaert 1995, Uye \& Liang 1998); given the value was only $32.2 \mathrm{mgC} \mathrm{m}^{-3} \mathrm{yr}^{-1}$ at the Solent site, it must be regarded as having unusually low copepod production.

Although production by nauplii is not included in the present study, this does not typically exceed $25 \%$ of copepod total production (Mullin 1988, Laing et al. 1996, Liang \& Uye 1996). The inclusion of estimates of production for meroplanktonic larvae and other holoplankton at the Calshot site would increase the mesozooplankton production value. In addition, the harpacticoid copepod Euterpina acutifrons made up a significant fraction of total copepod numbers. Its abundance in the net samples was similar to that of the total calanoid abundance. As the adults of this species have a comparable weight to that of the calanoids, $\sim 1 \mu \mathrm{gC}$ (Conway et al. 1993), then their total biomass would have also been similar. Given the abundance of the other meroplankton and holoplankton groups (Table 3) and that they have similar body sizes, and assuming similar weight-specific growth and ingestion rates, then it is still unlikely that the role of the total mesozooplankton, either as producers or consumers, would have been more than 3.5 times greater than that of the calanoids whose mean annual abundance was $29 \%$ of the total.

Zooplankton may not in fact be the main consumers of suspended particulate carbon (including phytoplankton) in shallow coastal areas where benthic organisms can play an important role (Williams \& Collins 1986). Hirst (1996) made some estimates of macro-faunal production using data collected near Calshot during 1979 by Oyenekan (1981). Preliminary results suggested that macro-benthic production is lower than that of the calanoid copepods on an area basis. The benthic community has, however, seen a massive shift from biomass dominance by the bivalve Mercenaria mercenaria in 1979 , to the virtual absence of this species during this zooplankton investigation ( $M$. Sheader pers, obs.). Unfortunately no values are available for meiofaunal or microbenthos production in this area.

Table 3. Geometric mean abundance (trapezoidal integration) and range of the dominant zooplankton at Calshot during the 14 month investigation (calculated from the data of Hirst 1996)

\begin{tabular}{|lrc|}
\hline Group & $\begin{array}{c}\text { Geometric mean } \\
\text { abundance (ind. } \mathrm{m}^{-3} \text { ) }\end{array}$ & $\begin{array}{c}\text { Range min-max } \\
\text { (ind. } \mathrm{m}^{-3} \text { ) }\end{array}$ \\
\hline $\begin{array}{l}\text { Holoplankton } \\
\text { Calanoid copepodites }\end{array}$ & 642.2 & $8.6-2255.2$ \\
Cyclopoid copepodites & 3.1 & $0.0-19.2$ \\
Ostracods & 1.2 & $0.0-6.5$ \\
Oikopleura spp. & 109.5 & $0.0-1172.1$ \\
Euterpina acutifrons & 650.5 & $0.0-2524.3$ \\
Meroplankton & & \\
Cirripede larvae & 432.4 & $52.6-1242.1$ \\
Polychaete larvae & 40.6 & $4.4-188.7$ \\
Bivalve larvae & 70.7 & $0.0-313.0$ \\
Bryozoan larvae & 60.9 & $0.0-175.5$ \\
Ascidian larvae & 4.6 & $0.0-30.4$ \\
Gastropod larvae & 128.3 & $0.0-421.2$ \\
Harpacticoid copepodites & 59.5 & $4.4-466.5$ \\
(excluding Euterpina acutifrons) & \\
\hline
\end{tabular}


Although the estimate of ciliate production for Calshot is at the higher end of values for studies elsewhere (Table 2), their relative dominance over copepods is more extreme at the Calshot site because of the very low production by the calanoid copepods. Growth rates for copepods were determined from an empirical relationship which provides 'typical growth rates', and the low production rates are therefore a consequence of low biomass, with the maximum biomass reaching only $1818 \mu \mathrm{gC} \mathrm{m}^{-3}$. This is in contrast to other temperate estuarine and shelf waters maximum annual copepod or metazoan zooplankton biomass levels which often exceed 10 or even $100 \mathrm{mgC} \mathrm{m}^{-3}$ (Curl 1962, Durbin \& Durbin 1981, Tremblay \& Roff 1983, Kiørboe \& Nielsen 1994, Uye \& Liang 1998). Williams \& Collins' (1986) 12 mo investigation of the Bristol Channel (UK) did, however, give comparable maximum biomass levels, with the inner channel holoplankton biomass reaching an annual maximum of $\sim 1800 \mu \mathrm{gC} \mathrm{m}^{-3}$, and when including meroplankton the total biomass did not exceed $2800 \mu \mathrm{gC} \mathrm{m} \mathrm{m}^{-3}$

The question must be posed as to why copepod biomass and abundance were so low at the Calshot site while chlorophyll levels were high, typically $>2 \mu \mathrm{g} \mathrm{I}^{-1}$. There are several plausible reasons which may, acting in unison, bring about the untypical situation. Certainly flushing rates from the Solent are high, and whereas microbial populations have high rates of growth and hence are better able to cope with population loss, the low biomass presented by the calanoid copepods may be a direct consequence of an environment with high flush out. Information on the physics of the Solent is generally sparse, but the net change in tidal volume (i.e. the change in water volume between high and low water) for the Solent has been estimated at $540 \times 10^{6} \mathrm{~m}^{3}$ and $270 \times 10^{6} \mathrm{~m}^{3}$ for typical spring and neap tides respectively (Blain 1980). The annual inflow of freshwater to the Solent has been computed to be of the order $10^{9} \mathrm{~m}^{3}$, which is equivalent to $1.4 \times 10^{6} \mathrm{~m}^{3}$ per tidal cycle but varies considerably depending upon time of year. Tidal streams in the Solent to the west of Calshot are up to 4 knots, and to the east 2.5 knots (Webber 1980). There are no estimates of flushing time for the Solent although for Southampton Water estimates range from 3 to $5 \mathrm{~d}$ in winter and $20 \mathrm{~d}$ in summer (see Zinger 1989), this could result in major population losses. Species of the families Acartidae, Temoridae and Centropagiidae all produce resting eggs which can survive deposition in the sediments (Uye 1985), and these eggs may be the major contributors to the new population following winter (Marcus 1984). Winter residual population levels have been implicated as having significant control over the potentially achievable abundances later in the year (Roff et al. 1988), and loss during winter may be particularly important. The tides are strong in the area, and ebb tides are stronger than flood tides so that re-suspension of sediments could result in major washout of over-wintering eggs.

Measurements of suspended particulate matter within the mouth of the estuary were taken over the period May 1994 to May 1995 (Hirst 1996). Dry weight values of SPM were fairly constant at around $40 \mathrm{mg} \mathrm{l}^{-1}$, while the ash weight of SPM was typically $\sim 10 \mathrm{mg} \mathrm{l}^{-1}$ It has previously been suggested that suspended seston of low food value could disrupt feeding, or reduce the feeding or digestion efficiency in some manner (Burkill \& Kendall 1982). High suspended sediment concentrations have been shown to reduce the total survival of Acartia tonsa nauplii, as well as inhibiting development rate and fecundity of survivors (Sellner et al. 1987), while Calanus helgolandicus has reduced growth, reduced survival, lower stage weights and reduced ovary development rates under conditions of high sediment concentrations (Paffenhöfer 1972). Irigoien \& Castel (1995) described important effects of suspended particulate on the feeding and growth success of $A$. bifilosa in a turbid estuarine environment, and although the values of chl a/SPM found by Hirst (1996) were generally higher (and therefore assumed not to be as inhibiting), they did fall to levels which can be considered to result in reduced growth rates.

Southampton Water is highly industrialised, the city of Southampton is to the north, and major chemical and oil refineries are based on the western shore of Southampton Water. In the mid to late 1980s, levels of non-volatile petroleum hydrocarbons (PHC) in sea water from the main Southampton Water channel ranged between $\sim 40$ and $500 \mu \mathrm{g} \mathrm{I}^{-1}$, while in sediments they were between 80 and $1200 \mu \mathrm{g}$ (g sediment dry weight $)^{-1}$ (Bianchi 1993). The viability of copepod eggs deposited in marine sediments has been linked to the degree of hydrocarbon pollution in that sediment (Lindley et al. 1998), and waterborne concentrations of $\sim 100 \mu \mathrm{g} \mathrm{l}^{-1}$ total oil have been found to lead to dramatic reductions in viability of calanoid copepods in large enclosures (Davies et al. 1980). Oil concentrations below $1000 \mathrm{\mu g} \mathrm{l}^{-1}$ produce sub-lethal responses by zooplankton under laboratory conditions, and sub-lethal damage may occur when exposure is for days or weeks at oil concentrations between 50 and $300 \mu \mathrm{g} \mathrm{I}^{-1}$ (NRC 1985). If hydrocarbon levels in the area at the time of our investigation were similar to those in the $1980 \mathrm{~s}$ then they are certainly within the range which would have adversely affected the local zooplankton.

Acknowledgements. A.G.H. was funded by a Natural Environment Research Council Studentship (GT/4/92/261/A). We thank staff and crew of the RV 'Bill Conway' for their assistance during the field program. Our thanks go to Dave Conway for his patience in training A.G.H. in copepod staging 
and identification, and to Shin-Ichi Uye for constructive comments on an earlier draft of this paper.

\section{LITERATURE CITED}

Alcaraz M (1976) Description of Acartia margalefi, a new species of pelagic copepod, and its relationship with $A$. clausi. Invest Pesq 40:59-74

Antai AE (1989) Seasonal trophodynamics of bacterioplankton and heterotrophic microflagellates in Southampton Water. PhD thesis, University of Southampton

Båmstedt U (1986) Chemical composition and energy content. In: Corner EDS, O'Hara SCM (eds) The biological chemistry of marine copepods. Clarendon Press, Oxford, p 1-58

Berggreen U, Hansen B, Kiørboe T (1988) Food size spectra, ingestion and growth of the copepod Acartia tonsa: implications for the determination of copepod production. Mar Biol 99:341-352

Bianchi AP (1993) Studies of volatile organic compounds in the water and sediments of a British estuary-Southampton Water. PhD thesis, The Open University

Blain WR (1980) Tidal hydraulics of the west Solent. PhD thesis, University of Southampton

Burkill PH (1982) Ciliates and other microplankton components of a nearshore food-web: standing stocks and production processes. Annls Inst Oceanogr Paris (NS) 58: $335-350$

Burkill PH, Kendall TF (1982) Production of the copepod Eurytemora affinis in the Bristol Channel. Mar Ecol Prog Ser $7: 21-31$

Castro-Longoria E (1998) Seasonal and spatial distribution patterns of the congeneric group Acartia in the SolentSouthampton Water estuarine system, with specifc reference to aspects of their fecundity. PhD thesis, University of Southampton

Castro-Longoria E, Williams JA (1996) First report of the presence of Acartia margalefi (Copepoda: Calanoida) in Southampton Water and Horsea Lake, UK. J Plankton Res 18:567-575

Chisholm LA, Roff JC (1990) Abundances, growth rates, and production of tropical neritic copepods off Kingston, Jamaica. Mar Biol 106:71-77

Christou ED, Vernopoulos GC (1993) Length, weight and condition factor of Acartia clausi (Copepoda) in the Eastern Mediterranean. J Mar Biol Assoc UK 73:343-353

Conover RJ (1957) Notes on the seasonal distribution of zooplankton in Southampton Water with special reference to the genus Acartia. Ann Mag Nat Hist Ser 12, 10:63-67

Conway DVP, Tranter PRG, Coombs SH (1993) Digestion of natural food by larval and post-larval turbot Scophalmus maximus. Mar Ecol Prog Ser 100:221-231

Curl H (1962) Standing crops of carbon, nitrogen, and phosphorus and transfer between trophic levels, in continental shelf waters south of New York. Rapp PV Réun Cons Int Explor Mer 153:183-189

Davies JM, Baird IE, Massie LC, Hay SJ, Ward AP (1980) Some effects of oil-derived hydrocarbons on a pelagic food web from observations in an enclosed ecosystem and a consideration of their implications for monitoring. Rapp PV Réun Cons Int Explor Mer 179:201-211

Durbin AG, Durbin EG (1978) Length and weight relationships of Acartia clausi from Narragansett Bay, R.I. Limnol Oceanogr 23:958-969

Durbin AG, Durbin EG (1981) Standing stock and estimated production rates of phytoplankton and zooplankton in Narragansett Bay, Rhode Island. Estuaries 4:24-41
Durbin EG, Durbin AG, Smayda TJ, Verity PG (1983) Food limitation of production by adult Acartia tonsa in Narragansett Bay, Rhode Island. Limnol Oceanogr 28: $1199-1213$

Escaravage V, Soetaert K (1995) Secondary production of the brackish copepod communities and their contribution to the carbon fluxes in the Westerschelde estuary (The Netherlands). Hydrobiologia 311:103-114

Evans $F$ (1981) An investigation into the relationship of sea temperature and food supply to the size of the planktonic copepod Temora longicornis Müller in the North Sea. Estuar Coast Shelf Sci 13:145-158

Fenchel T, Finlay BJ (1983) Respiration in heterotrophically living protozod. Microb Ecol 9:99-122

Finlay BJ (1978) Community production and respiration by ciliated protozoa in the benthos of a small eutrophic loch. Freshwat Biol 8:327-341

Heinle DR (1966) Production of a calanoid copepod, Acartia tonsa, in the Patuxent River estuary. Chesapeake Sci 7 : $59-74$

Hirst AG (1996) Zooplankton production and energy flowtowards a biological model of Southampton Water. PhD thesis, University of Southampton

Hirst AG, Lampitt RS (1998) Towards a global model of in situ weight-specific growth in marine planktonic copepods. Mar Biol 132:247-257

Hirst AG, Castro-Longoria E (1998) Acartia bifilosa (Copepoda: Calanoida): a clarification of the species and its varieties inermis and intermedia. J Plankton Res 20: $1119-1130$

Iriarte A, Purdie DA (1994) Size distribution of chlorophyll a biomass and primary production in a temperate estuary (Southampton Water): the contribution of photosynthetic picoplankton. Mar Ecol Prog Ser 115:283-297

Irigoien X. Castel J (1995) Feeding rates and productivity of the copepod Acartia bifilosa in a highly turbid estuary; the Gironde (SW France). Hydrobiologia 311:115-125

Jerling HL, Wooldridge TH (1991) Population dynamics and estimates of production for the calanoid copepod Pseudodiaptomus hessei in a warm temperate estuary. Estuar Coast Shelf Sci 33:121-135

Kifle D (1992) Seasonal and spatial variations in species composition, abundance, biomass and primary production of phytoplankton in Southampton Water. PhD thesis, University of Southampton

Kimmerer WJ, McKinnon AD (1987) Growth, mortality, and secondary production of the copepod Acartia tranteri in Westernport Bay, Australia. Limnol Oceanogr 32:14-28

Kiørboe T, Nielsen TG (1994) Regulation of zooplankton biomass and production in a temperate coastal ecosystem. 1. Copepods. Limnol Oceanogr 39:493-507

Klein Breteler WCM, Fransz HG, Gonzalez SR (1982) Growth and development of four calanoid copepod species under experimental and natural conditions. Neth J Sea Res 16 : 195-207

Landry MR (1978) Population dynamics and production of a planktonic marine copepod, Acartia clausii, in a small temperate lagoon on San Juan Island, Washington. Int Rev Ges Hydrobiol 63:77-119

Laurence GC (1976) Caloric values of some North Atlantic calanoid copepods. Fish Bull 74:218-220

Laybourn JEM, Finlay BJ (1976) Respiration energy losses related to cell weight and temperature in ciliated protozoa. Oecologia 24:349-355

Leakey RJG, Burkill PH, Sleigh MA (1992) Planktonic ciliates in Southampton Water abundance, biomass, production, and role in pelagic carbon flow. Mar Biol 114:67-83 
Liang D, Uye S (1996) Population dynamics and production of the planktonic copepods in a eutrophic inlet of the Inland Sea of Japan. II. Acartia omorii. Mar Biol 125: $109-117$

Liang D, Uye S, Onbé T (1996) Population dynamics and production of the planktonic copepods in a eutrophic inlet of the Inland Sea of Japan. I. Centropages abdominalis. Mar Biol 124:527-536

Lindley JA, George CL, Evans SV, Donkin P (1998) Viability of calanoid copepod eggs from intertidal sediments: a comparison of three estuaries. Mar Ecol Prog Ser 162: $183-190$

Marcus NH (1984) Recruitment of copepod nauplii into the plankton: importance of diapause eggs and benthic processes. Mar Ecol Prog Ser 15:47-54

McLaren IA, Tremblay MJ, Corkett CJ, Roff JC (1989) Copepod production on the Scotian Shelf based on life-history analyses and laboratory rearings. Can J Fish Aquat Sci 38: $77-83$

Montagnes DJS, Lynn DH, Roff JC, Taylor WD (1988) The annual cycle of heterotrophic planktonic ciliates in the waters surrounding the Isles of Shoals, Gulf of Maine: an assessment of their trophic role. Mar Biol 99:21-30

Moraitou-Apostolopoulou M (1975) Seasonal variations in length of three copepods in Saronic Bay (Greece). Boll Pesca Piscic Idrobiol 30:93-99

Mullin MM (1988) Production and distribution of nauplii and recruitment variability - putting the pieces together. In: Rothschild BJ (ed) Towards a theory on biological-physical interactions in the world ocean. Kluwer Academic Publishers, New York, p 297-320

Nielsen TG, Kiørboe T (1994) Regulation of zooplankton biomass and production in a temperate, coastal ecosystem. 2. Ciliates. Limnol Oceanogr 39:508-519

NRC - National Research Council (1985) Oil in the sea: inputs, fates and effects. National Academic Press, Washington

Omori M, Ikeda T (1984) Methods in marine zooplankton ecology. John Wiley and Sons, New York

Platt T (1971) The annual production by phytoplankton in St. Margaret's Bay, Nova Scotia. J Cons Int Explor Mer 33: 324-334

Oyenekan JA (1981) Community structure and production of the benthic macro-infauna of Southampton Water. PhD thesis, University of Southampton

Paffenhöfer GA (1972) The effects of suspended 'red mud' on mortality, body weight, and growth of the marine planktonic copepod, Calanus helgolandicus. Limnol Oceanogr $21: 39-50$

Richman S (1958) The transformation of energy by Daphnia pulex. Ecol Monogr 28:273-291

Raymont JEG Carrie BGA (1964) The production of zooplankton in Southampton Water. Int Rev Ges Hydrobiol 49: $185-232$

Roff JC, Middlebrook K, Evans F (1988) Long-term variability in North Sea zooplankton off the Northumberland coast:

Editorial responsibility: Otto Kinne (Editor),

Oldendorf/Luhe, Germany productivity of small copepods and analysis of trophic intercations. J Mar biol Assoc UK 68:143-164

Roff JC, Hopcroft RR, Clarke C, Chisholm LA, Lynn DH, Gilron GL (1990) Structure and energy flow in a tropical neritic planktonic community off Kingston, Jamaica. In: Barnes $M$, Gibson RN (eds) Trophic relationships in the marine environment. Proceedings of the 24th European Marine Biology Symposium. Aberdeen University Press, Aberdeen, p 266-280

Sellner KG, Bundy MH, Deming JW (1987) Effects of suspended sediments on the estuarine copepod Acartia tonsa. EOS 68:331

Straile D (1997) Gross growth efficiencies of protozoan and metazoan zooplankton and their dependence on food concentration, predator-prey weight ratio, and taxonomic group. Limnol Oceanogr 42:1375-1385

Sylaios G, Boxall SR (1998) Circulation and mixing of a partially-mixed estuary. In: Dronkers J, Scheffers MBAM (eds) Physics of estuaries and coastal seas. Balkema, Rotterdam, $\mathrm{p}$ 47-54

Tremblay MJ, Roff JC (1983) Production estimates for Scotian Shelf copepods based on mass specific $P / B$ ratios. Can J Fish Aquat Sci 40:749-753

Uye SI (1982) Population dynamics and produciton of Acartia clausi Giesbrecht (Copepoda: Calanoida) in inlet waters. J Exp Mar Biol Ecol 50:255-271

Uye SI (1985) Resting egg production as a life history strategy of marine planktonic copepods. Bull Mar Sci 37 : $440-449$

Uye SI, Iwai Y, Kasahara S (1982) Reproductive biology of Pseudodiaptomus marinus in the central part of the Inland Sea of Japan. Bull Plankton Soc Japan 29:25-35

Uye SI, Kuwata H, Endo T (1987) Standing stock and production rates of phytoplankton and planktonic copepods in the inland sea of Japan. J Oceanogr Soc Japan 42:421-434

Uye SI, Liang D (1998) Copepods attain high abundance, biomass and production in the absence of large predators but suffer cannibalistic loss. J Mar Syst 15:495-501

Uye SI, Shimazu T (1997) Geographical and seasonal variations in abundance, biomass and estimated production rates of meso- and macrozooplankton in the Inland Sea of Japan. J Oceanogr 53:529-538

Verity PG (1987) Abundance, community composition, size distribution, and production rates of tintinnids in Narragansett Bay, Rhode Island. Estuar Coast Shelf Sci 24: $671-690$

Webber NB (1980) Hydrology and water circulation in the Solent. In: The Solent estuarine system-an assessment of present knowledge. Publs Nat Env Res Counc, Swindon (Ser C) 22:25-35

Williams R, Collins NR (1986) Seasonal composition of meroplankton and holoplankton in the Bristol Channel. Mar Biol 92:93-101

Zinger I (1989) Zooplankton community structure in Southampton Water and its potential response to estuarine chronic oil pollution. PhD thesis, University of Southampton

Submitted: May 13, 1998; Accepted: October 20, 1998 Proofs received from author(s): January 25, 1999 